\section{Phillips Sees the Continuing Evolution of MRS}

Since she joined the Materials Research Society over ten years ago, Julia Phillips has seen tremendous changes in MRS and the materials community. Stepping into the role of MRS president for 1995, Phillips anticipates further changes.

She sees the executive committee continuing to pull back from day-to-day operations of MRS as the infrastructure and capabilities of MRS Headquarters continue to improve to handle such duties. As MRS staff coordinates the logistics of the technical meetings, publications, and member services, volunteers on council, the various committees, and the executive committee can focus on new challenges and opportunities. Carl Thompson, first vice president, will spearhead the Society's participation in electronic publishing; Robert Hull, second vice president, will concentrate on the Short Course Program; immediate past president John Bravman will deal with issues surrounding governance effectiveness; Kay Hays will work on investment policy matters; and secretary Carl Koch will focus on member needs.

An important project on Phillip's agen$\mathrm{da}$ is the Society's participation in the Federation of Materials Societies (FMS) (see FMS coverage in next article). Funding for materials research in the U.S. is changing. During the "Cold War," science funding from the federal government was considered an entitlement. Now that the U.S. has entered its post-cold-war stage, Washington is pulling back from this position. Phillips intends to relay the message to Washington that materials research must remain a national priority if the quality of life is to continue to improve. The public affairs committee will determine which materials issues are especially important to MRS, then will work with other materials societies through FMS to provide a voice for materials scientists to policy makers in Washington.

With the shift in the U.S. government's interests comes an evolution in job descriptions of MRS members. While some industries are downsizing, others, mostly small businesses, are growing. Along with materials research, materials scientists are entering nontraditional positions such as investment banking or management consulting. Materials researchers are also increasing their involvement with environmental and manufacturing interests. By measuring the pulse of changes in the members' needs, Phillips will keep MRS ahead of the curve.

The steps Phillips has taken leading her to materials research began during child- hood. She became interested in astronomy in elementary school. She was fascinated when a teacher introduced the concept of triangulation in an experiment measuring the size of large rectangles of masking tape on the floor of the school corridor. The teacher then explained how the method could be extended to measure the distances to stars. Phillips majored in physics at the College of William and Mary, intending to pursue a career in astronomy. After considering the implications of such a choice on her lifestyle, she elected instead to perform her PhD thesis research in atomic physics at Yale University. Upon joining AT\&T Bell Laboratories, Phillips moved into materials research where she is now technical manager of the Thin Film Research Group. Her research centers on heteroepitaxy and thin film growth of diverse materials, most recently magnetic oxides, novel transparent conducting materials, and high temperature superconductors.

One pattern that remains consistent,
MRS Council voted to join the Federation of Materials Societies (FMS) for a twoyear trial period. FMS is a consortium of over a dozen technical societies representing some 800,000 individual members active in promoting the effective and economic use of materials.

During the FMS Trustees Meeting on December 9, 1994, Julia M. Phillips, now the president of MRS, indicated the Society's interest in participating in a number of committees. Ron Kelley, the MRS public affairs representative in Washington, will serve on a committee formed to develop the FMS workshop on Materials Policy: New Thrusts and the New Congress, to be held in Washington on March 15, 1995. The Society is interested in volunteers to represent MRS in a half-day forum on pre-college education, to be held in Washington on March 13, 1995.

John Bravman, as immediate past president of MRS, is an FMS Trustee. He will represent MRS at the four Trustees Meetings per year.

MRS will have a representative on the Government Liaison Committee, which is the major policy group of FMS. The Government Liaison Committee guides

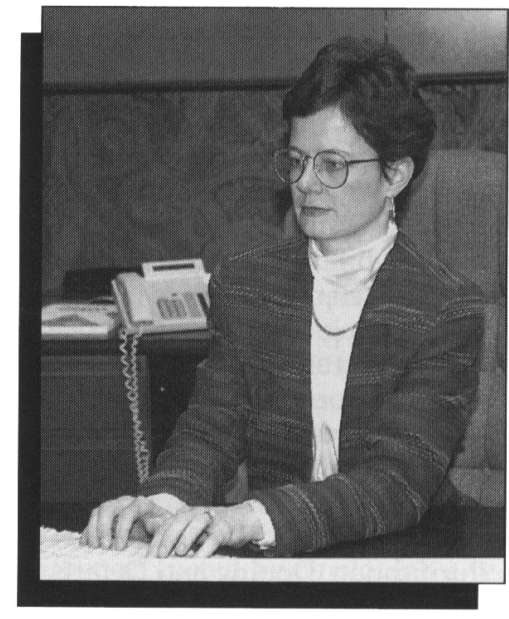

Julia Phillips

however, and differentiates MRS from other societies, according to Phillips, is the involvement of volunteers in the Society's activities. Members do not simply "show up" at the Meetings; they create the Meetings. They determine the directions MRS takes, which Phillips sees as the key to the vitality of MRS.

\title{
MRS Joins the Federation of Materials Societies
}

FMS in providing an "umbrella" under which materials policy can be related to various groups in the federal government such as the congressional committees, the National Science and Technology Council, and other federal agencies.

The MRS Council decided that participation with FMS would enhance several of the Society's interests. The Society can exchange information with the other member societies through the trustees meetings, committees, and FMS-sponsored meetings and workshops. MRS can share in the visibility of the materials community in Washington brought about by the active participation in this area by FMS for over 20 years. Furthermore, MRS has increased its opportunities for joint programming and cosponsorship of meetings, and can be involved in the planning of FMS biennial conferences on national materials policy and other topical meetings. The last FMS biennial conference was held in Williamsburg, Virginia from June 13-16, 1994 (see MRS Bulletin XIX, No. 8, From Washington department for coverage), and will hold its next conference on June 17-20, 1996. 